This is a self-archived version of an original article. This version may differ from the original in pagination and typographic details.

Author(s): Mero, Joel

Title: The effects of two-way communication and chat service usage on consumer attitudes in the e-commerce retailing sector

Year: 2018

Version: Accepted version (Final draft)

Copyright: (c) Institute of Applied Informatics at University of Leipzig 2018.

Rights: In Copyright

Rights url: http://rightsstatements.org/page/InC/1.0/?language=en

Please cite the original version:

Mero, J. (2018). The effects of two-way communication and chat service usage on consumer attitudes in the e-commerce retailing sector. Electronic Markets, 28(2), 205-217.

https://doi.org/10.1007/s12525-017-0281-2 


\title{
The effects of two-way communication and chat service usage on consumer attitudes in the e- commerce retailing sector
}

\author{
Abstract \\ In e-commerce retailing (e-retailing), where competitors are only one click away and prices are easy to compare, \\ providing superior customer service and reciprocal communication via a company's website are important \\ aspects of attracting and retaining customers. One increasingly popular solution to improve customer service is a \\ "live chat" interface that allows consumers to have real-time conversations online with customer service agents. \\ As the literature on the impacts of real-time communication via live chat is currently very limited, this study \\ develops and tests a model that demonstrates the moderating effects of a chat service on the relationship between \\ two-way communication (i.e., a core element of perceived website interactivity) and customer satisfaction, trust, \\ repurchase and word-of-mouth (WOM) intentions. The data for this study were collected via an online survey (N \\ $=6,783$ ) targeting the existing customers of five e-retailers that actively utilize live chats as a customer service \\ tool. The study results show that the extent to which a consumer perceives that an e-retailer is dedicated to \\ fostering two-way communication between the consumer and the seller has significant effects on trust, \\ satisfaction, and repurchase and WOM intentions. Moreover, the results of a multi-group analysis show that the \\ use of a chat service positively moderates these relationships.
}




\section{Introduction}

An increasing number of e-retailers are now providing real-time customer service on their websites via "live chat" interfaces, referred to as a chat service in this study. As a result, consumer online shopping is transforming from passive browsing of web pages to active interaction and dialogue with the sellers. In the e-commerce sector, consumers can use a chat service to obtain assistance for various issues, such as finding the right products for their needs, getting product details, and solving technical problems regarding the purchasing process. Chat conversations are typically prompted by the consumer, but a chat service agent may also proactively initiate a conversation upon observation from the click-stream data that a consumer may require assistance. The adoption of chat service among consumers has risen from 38\% in 2009 to $65 \%$ in 2015 (Forrester, 2016). Indeed, chat services are becoming the preferred option for obtaining customer support due to its real-time nature, which allows consumers to get instant responses to their queries (Econsultancy, 2017).

Contrary to offline shopping, online stores have traditionally lacked interaction between consumers and sellers, which has weakened the purchase intentions of the consumers (Jiang, Chan, Tan, \& Chua, 2010; Kang, Wang, Tan, \& Zhao, 2015). The emergence of chat services has provided customers with a tool that allows consumers to communicate with sales representatives in real time, and in that sense, to have a similar shopping experience to physical stores. Econsultancy (2017) finds that $92 \%$ of customers feel more satisfied to customer service when they use chat service compared to other modes of communication, such as email and phone. Moreover, chat service is likely to increase sales as the majority of consumers are likely to abandon their online purchases if they don't find quick answers to their queries (Econsultancy 2017; Forrester 2016).

Academic research on chat services is currently limited, but a few studies have found that the use of online chat services increases customers' purchase intentions (Kang et al., 2015; Lv, Wang, \& Huang, 2016). Lv et al. (2016) explain that real-time communication between a buyer and a seller via a chat service reduces the buyer's uncertainty when making purchase decisions. Other scholars explain the effect of chat service usage on higher purchase intentions via interactivity perceptions and relationship building. Specifically, Ou, Pavlou, and Davison (2014) combine computer-mediated communication (CMC) and guanxi theories and show that chat services facilitate repeat transactions with sellers by building swift guanxi (i.e., a buyer's perception of a swiftly formed interpersonal relationship with a seller) and trust by strengthening the buyers' perceptions of interactivity and presence. Furthermore, Song and Zinkhan (2008) investigate the effect of different online chat service features 
(e.g., response time, message type, and personalization) on interactivity perceptions and find that personalization is the strongest predictor of interactivity perceptions and website effectiveness.

Despite the theoretical progress, research on the use of chat services and perceived interactivity remains problematic for the following reasons: First, the existing studies posit the use of a chat service as an antecedent of perceived interactivity on the website. This study argues that the use of a chat service is a form of interaction, which makes the strong relationship between the use of a chat service and perceived interactivity axiomatic. Instead of investigating the link between an interaction (i.e., the use of chat service) and perceived interactivity, this study suggests that investigating the extent to which an interaction strengthens the link between perceived interactivity and positive consequences to consumer attitudes and behavioral intentions would add more to our understanding of the role of chat services on websites.

Second, while existing chat service research provides strong evidence of the relationship between perceived interactivity and purchase intention, little is known about other consequences of perceived interactivity and potential mediators of this relationship in an online chat service setting. Third, the perceived interactivity remains a highly elusive construct due to different definitions and dimensions (e.g., two-way communication, responsiveness, control) assigned to it by different scholars. As a result, it is difficult to compare the results of individual studies that use different dimensions of perceived interactivity. Another problem is that the dimensions of perceived interactivity may sometimes be in conflict, which makes it difficult to interpret the results. For example, a consumer may perceive that he or she is not in control of the website experience but believe that the website facilitates two-way communication via a chat service. While most studies investigate perceived interactivity as a composite of multiple dimensions, this study focuses on only one dimension of perceived interactivity (i.e., two-way communication), which crystallizes the object of the study and facilitates the interpretation of the study results.

Against this backdrop, I propose a model that seeks to explain the effects of the use of chat service on customer satisfaction, trust, repurchase intention, and word of mouth (WOM). Using interactivity theory (Kiousis 2002; Rafaeli, 1988), I propose that the effects of the use of a chat service on consumer attitudes and behavioral intentions result from consumers' higher perceptions of two-way communication on the website, which is one core element of website interactivity (e.g., Liu, 2003; McMillan \& Hwang, 2002; Song \& Zinkhan, 2008). The study objectives are as follows: (1) to investigate the effect of two-way communication perceptions on customer satisfaction, trust, repurchase intention, and WOM and (2) to examine the moderating effects of the use of a chat service on the links between two-way communication and the dependent variables. 
In the following section, I introduce the theoretical foundation and the key concepts of this study, and develop hypotheses for the study inquiry. I then proceed to describe the data collection and analysis methods. Finally, I present the study findings and discuss their contributions and limitations, as well as provide avenues for further research.

\section{Theoretical foundation}

\subsection{Interactivity}

According to Rafaeli (1988), a face-to-face conversation is a natural setting of interactivity, but such a conversation may also occur in mediated communication settings. In particular, the emergence of the Internet has provided an increasing amount of mediated communication settings, which are often referred to as computermediated environments (Hoffman \& Novak, 1996). Today, the term "interactivity" is highly associated with the Internet, digital media, and new communication technologies. This strong association is evidenced by the fact that digital media (and marketing) are often called "interactive media (and marketing)." The rise of the Internet has resulted in a growing body of literature that investigates interactivity in the context of digital media and digital technologies. However, the term interactivity remains ambiguous due to the variety of definitions that exist in the literature. Steuer (1992) considers interactivity as a property of a technology itself. Hoffman and Novak (1996) find two types of interactivity: person interactivity (i.e., human-human interaction via a medium) and machine interactivity (human-machine interaction within the medium). Others consider interactivity as a perception of individual users (e.g., Wu, 1999). Although the definitions vary, a number of scholars consider interpersonal or two-way communication to be a vital element of interactivity (see Table 1).

The definitions by Pavlik (1998) and DeFleur and Ball-Rokeach (1989) treat two-way communication synonymously with interactivity, thus underscoring the vital role of two-way communication as the core dimension of interactivity. In a similar vein, Kiousis (2002) defines interactivity as the degree to which communication technology can create a mediated environment in which participants can communicate and participate in reciprocal message exchanges and perceive the experience as a simulation of interpersonal communication. Kiousis' definition suits the needs of this study particularly well, as the definition 1) highlights two-way communication as an important determinant of interactivity, 2) is targeted to communication technologies and mediated environments (e.g., chat service), and 3) takes into account the human perceptions of interactivity. 
Table 1. Interactivity definitions related to interpersonal communication

\begin{tabular}{|ll|}
\hline Author & Interactivity definition \\
\hline $\begin{array}{l}\text { DeFleur \& Ball-Rokeach } \\
(1989, \text { p. 341) }\end{array}$ & $\begin{array}{l}\text { "The processes of communication that take on some of the characteristics of } \\
\text { interpersonal communication." }\end{array}$ \\
\hline $\begin{array}{l}\text { Ha \& James (1998, p. } \\
\text { 461) }\end{array}$ & $\begin{array}{l}\text { "The extent to which the communicator and the audience respond to, or are } \\
\text { willing to facilitate each other's communication needs." }\end{array}$ \\
\hline Kiousis (2002, p. 372) & $\begin{array}{l}\text { "The degree to which a communication technology can create a mediated } \\
\text { environment in which participants can communicate (one-to-one, one-to-many, } \\
\text { and many-to-many), both synchronously and asynchronously, and participate in } \\
\text { reciprocal message exchanges (third-order dependency). With regard to human } \\
\text { users, it additionally refers to their ability to perceive the experience as a } \\
\text { simulation of interpersonal communication and increase their awareness of } \\
\text { telepresence." }\end{array}$ \\
\hline Pavlik (1998, p. 137) & $\begin{array}{l}\text { "Two-way communication between source and receiver, or, more broadly } \\
\text { multidirectional communication between any number of sources and receivers." }\end{array}$ \\
\hline Rafaeli (1988, p. 111) & $\begin{array}{l}\text { "An expression of the extent that in a given series of communication exchanges, } \\
\text { any third (or later) transmission (or message) is related to the degree to which } \\
\text { previous exchanges referred to even earlier transmissions." }\end{array}$ \\
\hline $\begin{array}{l}\text { Williams et al. (1988, p. } \\
\text { 10) }\end{array}$ & \begin{tabular}{l} 
over, and can exchange roles in, their mutual discourse." \\
\hline
\end{tabular} \\
\hline
\end{tabular}

In line with Kiousis (2002), this study considers an online chat service as an interactive communication technology that can create a mediated environment in which a customer and chat service agent can communicate synchronously and participate in reciprocal message exchanges. Instead of studying the interactivity of the online chat service as such, this study focuses on the extent to which consumers perceive a website to facilitate two-way communication. Specifically, the study explores the consequences of two-way communication perceptions on ecommerce websites and the extent to which the use of a chat service strengthens the effect of two-way communication perceptions on consumer attitudes and behavioral intentions. Notably, the majority of authors consider (perceived) interactivity broader than just two-way communication. Consequently, this study uses the term "two-way communication" rather than interactivity to crystallize the object of the study inquiry.

\subsection{Defining key variables}

Two-way communication may occur when 1) the message exchanges in sequence relate to each other, and later messages take into account the relatedness of earlier messages, and when 2) one communicating party sends a message, he or she should be able to receive a fast response (Hoffman \& Novak, 1996; Kiousis, 2002; Liu, 2003; Rafaeli, 1988). As a theoretical construct, two-way communication derives from the concept of perceived interactivity. Perceived interactivity is typically operationalized as a combination of dimensions. However, due 
to different definitions of interactivity, the dimensions of perceived interactivity vary from study to study. For example, Liu (2003) includes active control, two-way communication, and synchronicity as the dimensions of perceived interactivity. Wu (2006) includes control, responsiveness, and personalization while McMillan and Hwang (2002) include communication, control of navigation and choices, time to load and find, and three additional overlapping dimensions. In line with the interactivity definition adopted in this study, which highlights interpersonal communication mediated via communication technology, this study focuses on two-way communication and conceptualizes it as the core dimension of interactivity. Specifically, the study focuses on consumer perceptions of two-way communication on the website and operationalizes two-way communication as the extent to which consumers believe that the website facilitates interpersonal communication between the eretailer and its customers (Liu, 2003).

Trust has been conceptualized in many different ways. Some authors consider trust as a conative or behavioral construct (Ganesan, 1994; Mayer, Davis, \& Schoorman, 1995). Other scholars emphasize cognitive and emotional aspects of trust and suggest that there is a relationship between trust evaluations and behavioral consequences that is likely to be influenced by other contextual factors (Morgan \& Hunt, 1994; Sirdeshmukh, Singh, \& Sabol, 2002). Morgan and Hunt (1994) explain that trust exists when one party has confidence in the reliability and integrity of the exchange partner. Similarly, Doney and Cannon (1997) define trust as the perceived credibility and benevolence of a target of trust, and this is the definition adopted in this study. This definition indicates that the consumer can rely on the e-retailer's statements and believe that the e-retailer is concerned with his or her personal needs.

Satisfaction is the extent to which consumers are content with the total purchase and consumption experience (Fornell, Johnson, Anderson, Cha, \& Bryant, 1996). The definition suggests that satisfaction cannot be divided into online and offline satisfaction because it is an outcome of the whole purchase and consumption process, which can partly occur online and partly offline. This study follows the same logic and operationalizes satisfaction as the consumers' total satisfaction with an e-retailer.

Repurchase Intention and WOM: Repurchase intention addresses the consumer's self-reported likelihood of engaging in repurchase behavior (Ha, Janda, \& Muthaly, 2010; Rose, Clark, Samouel, \& Hair, 2012). On the other hand, WOM is defined as "informal communications directed at other consumers about the ownership, usage, or characteristics of particular goods and services and/or their sellers" (Westbrook, 1987, p. 261). This study is specifically interested in the consumers' WOM intentions regarding the e-retailer. It is noteworthy that repurchase intention and WOM intention are often conceptualized as components of customer loyalty (e.g., 
Zeithaml, Berry, \& Parasuraman, 1996). However, I follow Söderlund (2006), whose study supports the argument that repurchase intention and WOM should be considered separate constructs. Indeed, various authors have followed the same logic and modeled repurchase intention and WOM as individual constructs (e.g., Gruen, Osmonbekov, \& Czaplewski, 2006; Jones \& Reynolds, 2006). Accordingly, this study operationalizes repurchase intention as the consumer's perceived likelihood of repurchasing on the e-commerce store, and WOM as the consumer's perceived likelihood of recommending the e-retailer to others.

\subsection{Research model and hypothesis development}

The research model of this study posits two-way communication as an independent variable and the use of chat service as a moderating variable, and it demonstrates how they are linked with consumer trust, satisfaction, repurchase intention, and WOM based on the existing literature (Figure 1).

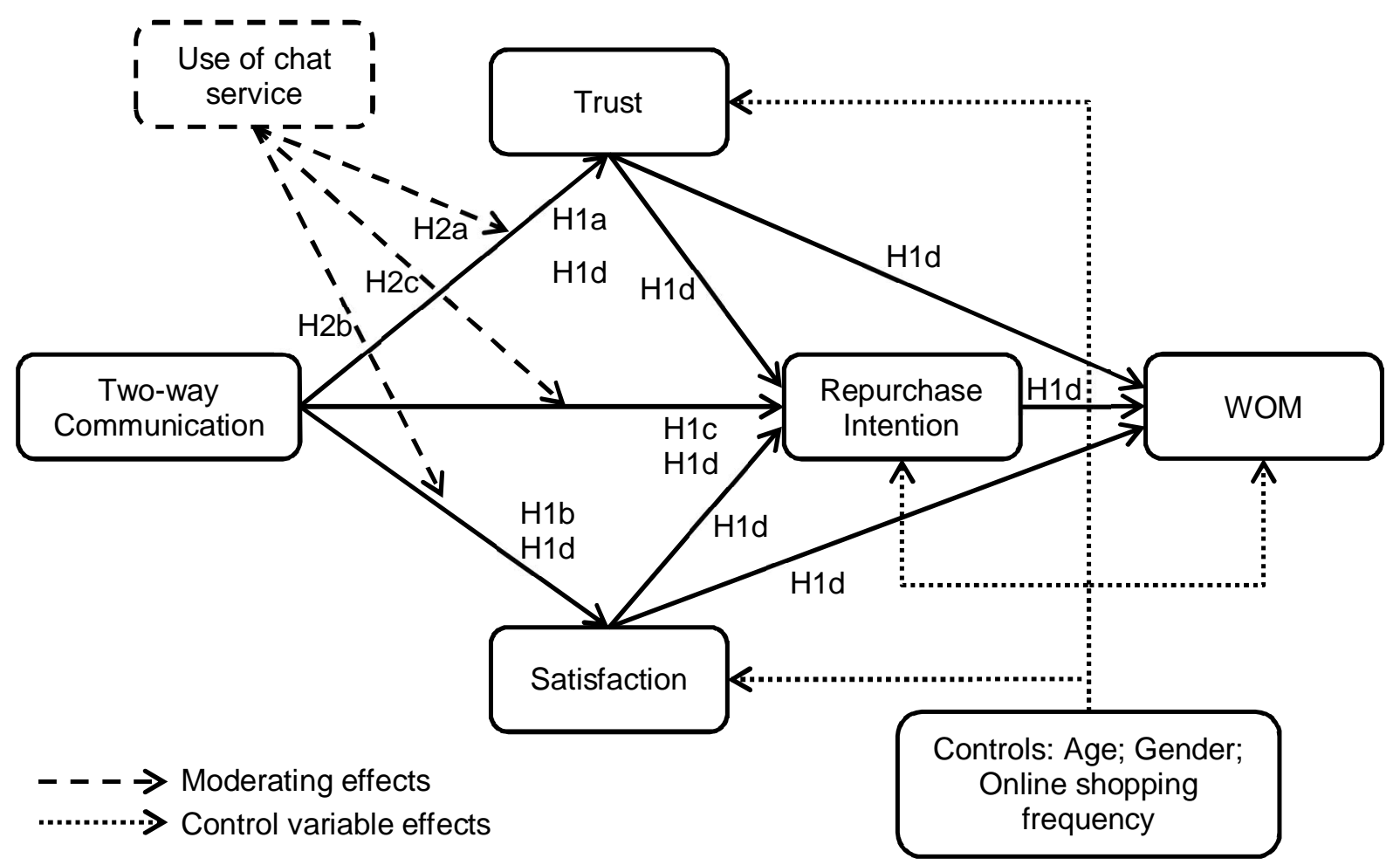

Figure 1. Research model and hypotheses

The positive effects of trust on repurchase intention, trust on WOM, satisfaction on repurchase intention, satisfaction on WOM, and repurchase intention on WOM have been confirmed in numerous studies (see Table 2). Therefore, I do not explicitly discuss or hypothesize these relationships. Instead, I include these relationships into the research model and focus on the effects of two-way communication and the use of chat service in the hypotheses of this study. 
Table 2. Literature on established relationships

\begin{tabular}{|ll|}
\hline Relationship & Related literature (confirming the relationship) \\
\hline Trust $\rightarrow$ Repurchase Intention & $\begin{array}{l}\text { (e.g., Chiu, Chang, Cheng, \& Fang, 2009; Ha et al., 2010; Ou } \\
\text { et al., 2014; Rose et al., 2012) }\end{array}$ \\
\hline Trust $\rightarrow$ WOM & (e.g., Chiou, Droge, \& Hanvanich, 2002; Gremler, Gwinner, \& \\
& Brown, 2001; Kim, Kim, \& Kim, 2009; Ranaweera \& Prabhu, \\
& 2003) \\
\hline Satisfaction $\rightarrow$ Repurchase Intention & (e.g., Anderson \& Srinivasan, 2003; Ha et al., 2010; Khalifa \& \\
& Liu, 2007; Ribbink, Riel, Liljander, \& Streukens, 2004; Rose et \\
& al., 2012) \\
\hline Satisfaction $\rightarrow$ WOM & (e.g., Brown, Barry, Dacin, \& Gunst, 2005; Heitmann, \\
& Lehmann, \& Herrmann, 2007; Hennig-thurau, Gwinner, \& \\
Gremler, 2002; Söderlund, 2006; Wangenheim \& Bayón, 2007) & (e.g., Munnukka, Karjaluoto, \& Tikkanen, 2015; Sichtmann, \\
\hline Repurchase Intention $\rightarrow$ WOM & 2007) \\
\hline
\end{tabular}

If a consumer perceives that a website facilitates two-way communication, she or he believes that the eretailer is open to dialogue and wants to listen to its customers (Liu, 2003). This study presumes that when a consumer perceives that the e-retailer is willing to listen and open to interpersonal communication, it is likely that the consumer's trust in and satisfaction with the e-retailer increases. Indeed, research shows that perceived interactivity on an e-commerce website has a positive effect on the trust in (Cyr, Head, \& Ivanov, 2009; Ou et al., 2014; Wu, Hu, \& Wu, 2010) and satisfaction with an e-retailer (Ballantine, 2005; Dholakia \& Zhao, 2009). As these studies investigate perceived interactivity multi-dimensionally where two-way communication is one of the dimensions, the results imply that two-way communication is associated with satisfaction and trust.

Since the majority of studies operationalize perceived interactivity as a second-order construct of multiple interactivity dimensions or as a single construct that integrates multiple interactivity dimensions, it is difficult to interpret the link between two-way communication to other variables. A notable exception is the experimental study by Song and Zinkhan (2008), who investigate perceived interactivity multi-dimensionally but report the effects of different perceived interactivity dimensions on outcome variables. They show that higher two-way communication perceptions are associated with greater repurchase behavior. Similarly, Kang et al. (2015) find a link between perceived interactivity and purchase intention. Notably, Kang's operationalization and measures of perceived interactivity rely heavily on the concept of two-way communication, offering further support for the link between two-way communication and repurchase intention.

Taken together, it is proposed that the extent to which a consumer perceives that an e-retailer is dedicated to facilitating two-way communication on the website influences the consumer's trust, satisfaction, and 
repurchase intention. As trust, satisfaction, and repurchase intention are strongly connected to WOM (see Table 2), I further suggest that two-way communication is indirectly linked to WOM. Accordingly, I formulate the following hypotheses:

HIa. Two-way communication has a positive direct effect on trust.

H1b. Two-way communication has a positive direct effect on satisfaction.

HIc. Two-way communication has a positive direct effect on repurchase intention.

HId. Two-way communication has a positive indirect effect on word-of-mouth.

Arguably, adding a real-time chat service to a website that allows reciprocal communication between the e-retailer and its customers is likely to result in positive two-way communication perceptions. However, previous research has provided evidence substantiating that the mere presence of interactive features on the website does not automatically affect consumers' perceptions of interactivity unless they have experience using them (McMillan \& Hwang, 2002; Mollen \& Wilson, 2010; Song \& Zinkhan, 2008). In line with this evidence, Ou et al. (2014) find that the use of an instant messenger (similar to live chat) at an e-commerce store leads to positive consumer perceptions and behaviors (e.g., trust and repurchase intention) through consumers' interactivity perceptions. Kang et al. (2015) find that the use of chat service increases the perceived interactivity of an e-commerce website, which is further linked to purchase intention. In sum, there is evidence that the use of chat service has positive impacts on two-way communication, which is linked to consumer attitudes.

To the best of my knowledge, however, no research has been conducted on the moderating effects of the use of chat service on the relationship between two-way communication and consumer attitudes. Arguably, the use of chat service inevitably leads to higher two-way communication perceptions because the chat service in itself is a form of computer-mediated two-way communication. Therefore, it is more relevant to study to what extent the use of chat service strengthens the relationship between two-way communication and its consequences. While previous research has found that the use of chat service is indirectly linked to positive outcomes through higher levels of interactivity (e.g., Kang et al., 2015; Ou et al., 2014; Song \& Zinkhan, 2008), this study proposes that the use of chat service acts as a moderator between two-way communication and trust, satisfaction, and repurchase intention. Accordingly, the following hypotheses are formulated:

H2a. The use of a chat service moderates the effect of two-way communication on trust, such that the effect is stronger for consumers who have used a chat service. 
H2b. The use of a chat service moderates the effect of two-way communication on satisfaction, such that the effect is stronger for consumers who have used a chat service.

H2c. The use of a chat service moderates the effect of two-way communication on repurchase intention, such that the effect is stronger for consumers who have used a chat service.

\section{Method}

The target population of the study was defined as consumers who had made a purchase on an e-commerce store which has a prominent chat service available. To reach a representative sample of the target population, the study was conducted in cooperation with five popular Finnish e-commerce stores operating in different retailing sectors (electronics, cosmetics, clothing, home decoration, and telecommunications), all of which had a similar chat service on their websites outsourced to a company called Finnchat. After discussions with the participating companies, the target sample was specified as all consumers who had made a purchase within the last 30 days from the participating e-commerce stores. The rationale for targeting the study at recent e-commerce buyers was to ensure that consumers would be able to remember and evaluate their shopping experience. The list of consumers that met the sampling criteria was obtained via the participating companies' transaction history (i.e., CRM system or equivalent). The data were collected in November 2014 via email that included a link to an online survey. In total, the survey was sent to 39,527 consumers. Each respondent evaluated only the ecommerce store where she or he had made the purchase. Customers were incentivized by raffling an iPad among respondents who were willing to participate. The email invitations to complete the survey resulted in 7,576 responses, producing a response rate of $19.1 \%$. In addition, the effective response rate of $74.9 \%$ was calculated by comparing those who clicked the survey link to those who completed the survey. In line with the target population criterion, the respondents who reported that they had not made a purchase within the last 30 days with the focal e-commerce store were removed from the pool of respondents. Invalid responses (i.e., the use of straight-lining) and incomplete responses were also ignored. This procedure left us with a final sample of 6,783 respondents, 1,754 of which $(25.9 \%)$ had used the e-retailers' chat service while 5,029 (74.1\%) had not. Minor differences were found between these two groups in terms of online shopping frequency, age, and gender (Table 3); chat-service users were found to shop online somewhat more frequently, and they consisted of a higher proportion of females. To further evaluate the effects of online shopping frequency, age, and gender on the study results, I included them in the research model as control variables (see Figure 1). Nonresponse bias was estimated using the method suggested by Armstrong and Overton (1977). Early respondents were compared with 
late respondents (i.e., first vs. fourth quartile of respondents) for all of the constructs, including the control variables. The comparison was made to each e-commerce store separately since the respondents' perceptions (e.g., their average satisfaction to the store) depended on which store they were evaluating. None of the tstatistics for difference in means were statistically significant. Thus, the nonresponse bias is not considered to be a problem.

All principal constructs were measured with reflective multi-item scales adapted from previous research (Appendix A). The use of chat service was measured by a categorical variable (yes or no): "Have you used the eretailer's chat service while visiting this e-commerce store?" To reduce the effect of a common method variance (CMV), I hid the respondents' identities, and the order of the construct items appeared in at random for each individual respondent.

Table 3. Respondents' background information

Online shopping frequency: In general, how often do you make purchases in online stores?

\begin{tabular}{|c|c|c|c|c|c|c|c|}
\hline & \multicolumn{2}{|c|}{$\begin{array}{l}\text { Once in a year } \\
\text { or less often }\end{array}$} & $\begin{array}{l}\text { A few times } \\
\text { per year }\end{array}$ & $\begin{array}{c}\text { Once per } \\
\text { month }\end{array}$ & $\begin{array}{l}\text { Once per } \\
\text { week }\end{array}$ & $\begin{array}{l}\text { Several times } \\
\text { per week }\end{array}$ & Total \\
\hline All respondents & $3.5 \%$ & & $3 \%$ & $42.3 \%$ & $10.3 \%$ & $1.6 \%$ & $\begin{array}{c}100.0 \% \\
(\mathrm{~N}=6,783)\end{array}$ \\
\hline $\begin{array}{l}\text { Group 1: } \\
\text { Chat users }\end{array}$ & $2.3 \%$ & & $8 \%$ & $46.2 \%$ & $11.6 \%$ & $2.1 \%$ & $\begin{array}{c}100.0 \% \\
(\mathrm{~N}=1,754)\end{array}$ \\
\hline $\begin{array}{l}\text { Group 2: } \\
\text { Non-chat users }\end{array}$ & $4.0 \%$ & & & $40.9 \%$ & $9.9 \%$ & $1.4 \%$ & $\begin{array}{c}100.0 \% \\
(\mathrm{~N}=5,029)\end{array}$ \\
\hline \multicolumn{8}{|c|}{ Age: What is your age (in years)? } \\
\hline & $\begin{array}{l}\text { Under } 25 \\
\text { years }\end{array}$ & $\begin{array}{l}26-35 \\
\text { years }\end{array}$ & $\begin{array}{l}36-45 \\
\text { years }\end{array}$ & $\begin{array}{l}46-55 \\
\text { years }\end{array}$ & $\begin{array}{l}56-65 \\
\text { years }\end{array}$ & $\begin{array}{c}\text { Over } 66 \\
\text { years }\end{array}$ & Total \\
\hline All respondents & $8.2 \%$ & $19.9 \%$ & $26.1 \%$ & $25.4 \%$ & $14.9 \%$ & $5.4 \%$ & $\begin{array}{c}100.0 \% \\
(\mathrm{~N}=6,783)\end{array}$ \\
\hline $\begin{array}{l}\text { Group 1: } \\
\text { Chat }\end{array}$ & $7.7 \%$ & $20.2 \%$ & $26.4 \%$ & $27.4 \%$ & $13.2 \%$ & $5.0 \%$ & $\begin{array}{c}100.0 \% \\
(\mathrm{~N}=1,754)\end{array}$ \\
\hline $\begin{array}{l}\text { Group 2: } \\
\text { Non-chat users }\end{array}$ & $8.3 \%$ & $19.8 \%$ & $26.0 \%$ & $24.8 \%$ & $15.5 \%$ & $5.6 \%$ & $\begin{array}{c}100.0 \% \\
(\mathrm{~N}=5,029)\end{array}$ \\
\hline \multicolumn{8}{|c|}{ Gender: What is your gender (female or male)? } \\
\hline \multicolumn{4}{|c|}{ Female } & \multicolumn{2}{|c|}{ Male } & \multicolumn{2}{|c|}{ Total } \\
\hline All respondents & & \multicolumn{2}{|c|}{$61.0 \%$} & \multicolumn{2}{|c|}{$39.0 \%$} & \multicolumn{2}{|c|}{$100.0 \%(\mathrm{~N}=6,783)$} \\
\hline Group 1: Chat & & \multicolumn{2}{|c|}{$64.2 \%$} & \multicolumn{2}{|c|}{$35.8 \%$} & \multicolumn{2}{|c|}{$100.0 \%(\mathrm{~N}=1,754)$} \\
\hline \multicolumn{2}{|c|}{ Group 2: Non-chat users } & \multicolumn{2}{|c|}{$60.0 \%$} & \multicolumn{2}{|c|}{$40.0 \%$} & \multicolumn{2}{|c|}{$100.0 \%(\mathrm{~N}=5,029)$} \\
\hline
\end{tabular}




\section{Results}

I used a partial least squares (PLS) approach and tested the conceptual model with the SmartPLS 3 software (Ringle, Wende, \& Becker, 2014). PLS was suitable for the research purpose because the data were found to be non-normal, and the primary focus was on the path relationships and variance explained of the target constructs rather than on the model fit per se (Sarstedt, Ringle, Smith, Reams, \& Hair, 2014). Moreover, PLS is an established method for analyzing parameter estimates across identified segments (i.e., chat users and non-chat users) and conducting multi-group analyses (Sarstedt, Henseler, \& Ringle, 2011).

\subsection{Measurement model}

The measurement model results were calculated separately for all respondents, chat users, and non-chat users, as shown in Table 4. The reflective indicators of the multi-item scales showed a high internal consistency, as the composite reliabilities of the constructs were well over .70, as recommended in the literature (Nunally \& Bernstein, 1994). The outer loadings largely supported indicator reliability; only one item of two-way communication had an outer loading under of .708 (see Appendix A) but it was kept in the model because it was theoretically relevant and statistically significant. The average variance extracted (AVE) values of all principal constructs exceeded the minimum level of .50, suggesting that on average, each construct explains more than half of the variance of its indicators (Hair, Hult, Ringle, \& Sarstedt, 2014).

Discriminant validity was achieved using the Fornell-Larcker criterion, which necessitates that the square root of the AVE from each construct should be greater than the correlation shared between the construct and other constructs in the model (Fornell \& Larcker, 1981). This result suggests that each construct in the model explains better the variance of its own indicators than the variance of other constructs. In addition, the heterotrait-monotrait ratio of correlations (HTMT) was used for assessing discriminant validity as there is evidence of its superior performance to Fornell-Larcker test (Henseler, Ringle, \& Sarstedt, 2015). By using the cutoff value of 0.9 (Gold, Malhotra, \& Segars, 2001; Teo, Srivastava, \& Jiang, 2008), the HTMT demonstrated that the estimated correlations between all the principal constructs were significantly smaller than one (see Table 5), indicating that the constructs differ from each other and providing further support for discriminant validity. To conclude, the scales of the model were found to be reliable and valid in the case of all three data segments. 
Table 4. Composite reliabilities, AVEs, discriminant validity, and descriptive statistics

\begin{tabular}{|c|c|c|c|c|c|c|c|}
\hline All respondents & $\mathbf{C R}$ & AVE & COM & TR & SAT & RI & WOM \\
\hline $\mathrm{COM}$ & .883 & .657 & .810 & & & & \\
\hline TR & .919 & .791 & .703 & .889 & & & \\
\hline SAT & .966 & .876 & .671 & .752 & .936 & & \\
\hline RI & .919 & .739 & .672 & .713 & .741 & .860 & \\
\hline WOM & .935 & .828 & .694 & .762 & .731 & .760 & .910 \\
\hline Mean & & & 5.08 & 5.74 & 8.00 & 5.47 & 5.28 \\
\hline SD & & & 1.40 & 1.19 & 1.63 & 1.41 & 1.38 \\
\hline Chat users & CR & AVE & COM & TR & SAT & RI & WOM \\
\hline COM & .883 & .656 & .810 & & & & \\
\hline TR & .926 & .808 & .755 & .899 & & & \\
\hline SAT & .970 & .890 & .719 & .773 & .943 & & \\
\hline RI & .917 & .735 & .708 & .736 & .774 & .857 & \\
\hline WOM & .942 & .844 & .726 & .788 & .776 & .785 & .919 \\
\hline Mean & & & 5.37 & 5.75 & 7.99 & 5.58 & 5.38 \\
\hline SD & & & 1.40 & 1.25 & 1.72 & 1.41 & 1.41 \\
\hline Non-chat users & $\mathbf{C R}$ & AVE & COM & TR & SAT & RI & WOM \\
\hline COM & .882 & .652 & .808 & & & & \\
\hline TR & .916 & .784 & .691 & .886 & & & \\
\hline SAT & .964 & .871 & .661 & .744 & .933 & & \\
\hline RI & .919 & .740 & .659 & .707 & .731 & .860 & \\
\hline WOM & .933 & .823 & .682 & .753 & .715 & .750 & .907 \\
\hline Mean & & & 4.99 & 5.75 & 8.00 & 5.43 & 5.24 \\
\hline SD & & & 1.38 & 1.16 & 1.60 & 1.40 & 1.37 \\
\hline
\end{tabular}

Notes: 1. CR: composite reliability; AVE: average variance extracted; COM: two-way communication; TR: trust; SAT: satisfaction; RI: repurchase intention; WOM: word-of-mouth; SD: standard deviation; 2. Bolded diagonal elements are square roots of the AVEs, and off-diagonal elements are construct correlations.

Table 5. Heterotrait-monotrait ratio of correlations

\begin{tabular}{|c|c|c|c|c|c|}
\hline All respondents & COM & TR & SAT & $\mathbf{R I}$ & WOM \\
\hline \multicolumn{6}{|l|}{ COM } \\
\hline TR & .810 & & & & \\
\hline SAT & .731 & .827 & & & \\
\hline RI & .754 & .812 & .805 & & \\
\hline WOM & .777 & .859 & .786 & .847 & \\
\hline Chat users & COM & TR & SAT & $\mathbf{R I}$ & WOM \\
\hline \multicolumn{6}{|l|}{ COM } \\
\hline TR & .870 & & & & \\
\hline SAT & .787 & .841 & & & \\
\hline RI & .800 & .832 & .836 & & \\
\hline WOM & .815 & .879 & .829 & .869 & \\
\hline Non-chat users & COM & TR & SAT & RI & WOM \\
\hline \multicolumn{6}{|l|}{ COM } \\
\hline TR & .800 & & & & \\
\hline SAT & .721 & .821 & & & \\
\hline RI & .738 & .807 & .795 & & \\
\hline WOM & .766 & .853 & .771 & .838 & \\
\hline
\end{tabular}

Notes: COM: two-way communication; TR: trust; SAT: satisfaction; RI: repurchase intention; WOM: word-ofmouth. 
To assess the CMV, I followed Podsakoff, MacKenzie, Lee, and Podsakoff (2003) by including in the PLS model a common method factor with indicators of all principal constructs and calculating each indicator's substantively explained variances by the method and the principal construct. When including all respondents in the calculation, the average variance explained by original factors was .83 (.85 and .83 for chat users and nonchat users, respectively), while that by the method factor was .03 (same result for chat and non-chat users), thus suggesting that the CMV was not of serious concern in this study.

\subsection{Structural model}

A path-weighting scheme was used to estimate the paths between the constructs. To determine the significance of each estimated path, I applied a standard bootstrapping procedure (two-sided) with 5,000 sub-samples consisting of the same number of cases as in the original sample (Hair et al., 2014). The same procedure of estimating paths between the constructs and bootstrapping was conducted separately for all segments (i.e., all respondents, chat users, and non-chat users). To analyze the differences of path estimates between chat users and non-chat users, I conducted a PLS-based multi-group analysis (PLS-MGA), which does not rely on distributional assumptions and is therefore the most appropriate method for PLS-based group comparisons (Henseler, Ringle, \& Sinkovics, 2009). In the PLS-MGA approach, the subsamples are exposed to separate bootstrap analyses, and the bootstrap outcomes serve as a basis for the hypothesis tests to determine whether the group differences are statistically significant (Henseler et al., 2009). The results of the analysis are presented in Table 6.

Overall, the results suggest that provided support for the theoretical model's applicability in explaining the dependent variables' variance by their predictor variables, as evidenced in the relatively high $R^{2}$ values. Notably, the $R^{2}$ values were higher in the chat users' subsample compared to non-chat users; in the chat users' subsample, the model explained $57 \%$ of the variance in trust, $52 \%$ in satisfaction, $68 \%$ in repurchase intention, and $74 \%$ in WOM, while the $R^{2}$ values for non-chat users were $48 \%, 44 \%, 63 \%$ and $68 \%$, respectively. All the $R^{2}$ value differences between groups were also statistically significant $(\mathrm{p}<.05)$, suggesting that the use of chat service improves the extent to which the model explains consumer attitudes and behavioral intentions in the context of e-retailing. 
Table 6. Structural model results, group differences, and indirect and total effects

\begin{tabular}{|c|c|c|c|c|c|c|c|c|}
\hline $\begin{array}{c}\text { Coefficient of } \\
\text { determination }=R^{2} \\
\text { (Predictive relevance } \\
=Q^{2} \text { ) }\end{array}$ & \multicolumn{2}{|c|}{ All respondents } & \multicolumn{2}{|c|}{$\begin{array}{l}\text { Group 1: } \\
\text { Chat users }\end{array}$} & \multicolumn{2}{|c|}{$\begin{array}{c}\text { Group 2: } \\
\text { Non-chat users }\end{array}$} & \multicolumn{2}{|c|}{$\begin{array}{c}\text { Difference } \\
\mid \mathbf{R}^{2} \text { of Group } 1 \text { - } \\
\mathbf{R}^{2} \text { of Group 2| }\end{array}$} \\
\hline Trust (TR) & \multicolumn{2}{|c|}{$.495(.391)$} & \multicolumn{2}{|c|}{$.573(.462)$} & \multicolumn{2}{|c|}{$.479(.375)$} & \multicolumn{2}{|c|}{$.094 * *$} \\
\hline Satisfaction (SAT) & \multicolumn{2}{|c|}{$.452(.396)$} & \multicolumn{2}{|c|}{$.517(.459)$} & \multicolumn{2}{|c|}{$.440(.383)$} & \multicolumn{2}{|c|}{$.077 * *$} \\
\hline $\begin{array}{l}\text { Repurchase intention } \\
\text { (RI) }\end{array}$ & \multicolumn{2}{|c|}{$.640(.471)$} & \multicolumn{2}{|c|}{$.676(.491)$} & \multicolumn{2}{|c|}{$.628(.463)$} & \multicolumn{2}{|c|}{$.048^{*}$} \\
\hline $\begin{array}{l}\text { Word-of-mouth } \\
\text { (WOM) }\end{array}$ & \multicolumn{2}{|c|}{$.691(.567)$} & \multicolumn{2}{|c|}{.735 (.616) } & \multicolumn{2}{|c|}{$.676(.550)$} & \multicolumn{2}{|c|}{$.059 * *$} \\
\hline $\begin{array}{l}\text { Path coefficient }=\boldsymbol{\beta} \\
\left(\text { effect } \text { size }=\mathrm{f}^{2}\right)\end{array}$ & \multicolumn{2}{|c|}{ All respondents } & \multicolumn{2}{|c|}{$\begin{array}{l}\text { Group 1: } \\
\text { Chat users }\end{array}$} & \multicolumn{2}{|c|}{$\begin{array}{c}\text { Group 2: } \\
\text { Non-chat users }\end{array}$} & \multicolumn{2}{|c|}{$\begin{array}{c}\text { Difference } \\
\mid \boldsymbol{\beta} \text { of Group 1 - } \\
\beta \text { of Group 2| }\end{array}$} \\
\hline $\begin{array}{l}\text { H1a; H2a: } \\
\text { COM } \rightarrow \text { TR }\end{array}$ & \multicolumn{2}{|c|}{$.703 * *(.970)$} & \multicolumn{2}{|c|}{$.755 * *(1.324)$} & \multicolumn{2}{|c|}{$.693 * *(.911)$} & \multicolumn{2}{|c|}{$.062 * *$} \\
\hline $\mathrm{AGE} \rightarrow \mathrm{TR}$ & \multicolumn{2}{|c|}{$-.028 * *(.002)$} & -.031 & $.002)$ & -.028 & $(.002)$ & & \\
\hline GEN $\rightarrow$ TR & $-.016 n$ & $(.001)$ & -.034 & $.003)$ & -.013 & $(.000)$ & & \\
\hline $\mathrm{OSF} \rightarrow \mathrm{TR}$ & $.015 n$ & $.000)$ & .036 & .003) & .0181 & $.001)$ & & \\
\hline $\begin{array}{l}\text { H1b; H2b: } \\
\text { COM } \rightarrow \text { SAT }\end{array}$ & $.667 *$ & (.804) & $.718^{*}$ & 1.057) & $.655^{*}$ & $.758)$ & & \\
\hline $\mathrm{AGE} \rightarrow \mathrm{SAT}$ & $.022 *$ & $.001)$ & .0021 & $.000)$ & $.029 *$ & $.001)$ & & \\
\hline GEN $\rightarrow$ SAT & $-.030 *$ & $(.002)$ & -.011 & $(.000)$ & -.040 & $(.003)$ & & \\
\hline $\mathrm{OSF} \rightarrow \mathrm{SAT}$ & -.024 & $.001)$ & -.003 & $(.000)$ & -.022 & $(.001)$ & & \\
\hline $\begin{array}{c}\text { H1c; H2c: } \\
\text { COM } \rightarrow \text { RI }\end{array}$ & $.223^{*}$ & $(.063)$ & .222 & $.058)$ & $.213^{*}$ & $.057)$ & & \\
\hline $\mathrm{TR} \rightarrow \mathrm{RI}$ & $.253 *$ & $(.064)$ & $.219^{*}$ & $.047)$ & $.269 *$ & $(.072)$ & & \\
\hline SAT $\rightarrow$ RI & $.395^{*}$ & $(.170)$ & $.442 *$ & $.216)$ & $.383^{*}$ & $.158)$ & & \\
\hline $\mathrm{AGE} \rightarrow \mathrm{RI}$ & $.031 *$ & $(.003)$ & .0051 & $.000)$ & $.039 *$ & $.004)$ & & \\
\hline GEN $\rightarrow$ RI & $-.091 *$ & $(.023)$ & -.091 & $(.025)$ & -.091 & $(.022)$ & & \\
\hline $\mathrm{OSF} \rightarrow \mathrm{RI}$ & $.051 *$ & $(.007)$ & $.054^{*}$ & $.009)$ & $.049 *$ & $.006)$ & & \\
\hline $\mathrm{TR} \rightarrow \mathrm{WOM}$ & $.353 *$ & $(.153)$ & $.349^{\prime}$ & $.162)$ & $.358 *$ & .153) & & \\
\hline $\mathrm{SAT} \rightarrow \mathrm{WOM}$ & $.197 *$ & $(.043)$ & $.237^{\prime}$ & $.065)$ & $.184^{*}$ & $.037)$ & & \\
\hline $\mathrm{RI} \rightarrow \mathrm{WOM}$ & $.366 *$ & $(.165)$ & .352 & $.160)$ & $.366^{*}$ & $.162)$ & & \\
\hline $\mathrm{AGE} \rightarrow \mathrm{WOM}$ & $-.046^{*}$ & $(.007)$ & -.043 & $(.007)$ & -.045 & $(.006)$ & & \\
\hline GEN $\rightarrow$ WOM & $.008 n$ & $(.000)$ & $.043^{*}$ & $.007)$ & -.004 & $(.000)$ & & \\
\hline $\mathrm{OSF} \rightarrow \mathrm{WOM}$ & $-.004 n$ & $(.000)$ & .0021 & $.000)$ & -.007 & $(.000)$ & & \\
\hline $\begin{array}{l}\text { Indirect and total } \\
\text { effects (principal } \\
\text { constructs) }\end{array}$ & All res] & ndents & $\begin{array}{l}\text { Gr } \\
\text { Cha }\end{array}$ & $\begin{array}{l}\text { 1: } \\
\text { isers }\end{array}$ & $\begin{array}{r}\text { Gr } \\
\text { Non-c }\end{array}$ & $\begin{array}{l}\text { 2: } \\
\text { t users }\end{array}$ & $\begin{array}{l}\text { Diff } \\
\text { |Gro } \\
\text { Gr }\end{array}$ & $\begin{array}{l}\text { ence } \\
01 \text { - } \\
02 \\
\end{array}$ \\
\hline & $\begin{array}{l}\text { Ind. } \\
\text { effect }\end{array}$ & $\begin{array}{l}\text { Total } \\
\text { effect }\end{array}$ & $\begin{array}{l}\text { Ind. } \\
\text { effect }\end{array}$ & $\begin{array}{l}\text { Total } \\
\text { effect }\end{array}$ & $\begin{array}{l}\text { Ind. } \\
\text { effect }\end{array}$ & $\begin{array}{l}\text { Total } \\
\text { effect }\end{array}$ & $\begin{array}{l}\text { Ind. } \\
\text { effect } \\
\text { differ. }\end{array}$ & $\begin{array}{l}\text { Total } \\
\text { effect } \\
\text { differ. }\end{array}$ \\
\hline $\mathrm{COM} \rightarrow \mathrm{RI}$ & $.441 * *$ & $.644 * *$ & $.483 * *$ & $.705 * *$ & $.437 * *$ & $.650 * *$ & $.046 *$ & $.055^{* *}$ \\
\hline H1d: COM $\rightarrow$ WOM & $.623 * *$ & $.623 * *$ & $.682 * *$ & $.682 * *$ & $.606 * *$ & $.606 * *$ & $.076 * *$ & $.076 * *$ \\
\hline $\mathrm{TR} \rightarrow \mathrm{WOM}$ & $.092 * *$ & $.446 * *$ & $.077 * *$ & $.426 * *$ & $.098 * *$ & $.456 * *$ & $.021 \mathrm{~ns}$ & $.030 \mathrm{~ns}$ \\
\hline $\mathrm{SAT} \rightarrow \mathrm{WOM}$ & $.144 * *$ & $.342 * *$ & $.155^{* * *}$ & $.393 * *$ & $.140 * *$ & $.324 * *$ & $.015 \mathrm{~ns}$ & $.069 *$ \\
\hline
\end{tabular}

Notes: 1. COM: two-way communication; GEN: gender; OSF: online shopping frequency.

2. $\mathrm{R}^{2}$ : coefficient of determination measures the proportion of a dependent variable's variance that is explained by its predictor variables; $\mathrm{Q}^{2}$ : a measure of predictive relevance based on the blindfolding procedure (values larger than zero indicate the path model's predictive relevance for the particular dependent variable).

3. $\mathrm{f}^{2}$ : effect size indicates the relative impact a construct has in producing the $\mathrm{R}^{2}$ value of the dependent variable (values larger than $.02, .15$, and .35 indicate small, medium, and large effects, respectively).

4. $* * \mathrm{p}<.01 ; * \mathrm{p}<.05 ; \mathrm{ns}=$ not significant. 


\subsection{Hypothesis testing}

Two-way communication was found to have significant direct effects on trust $(\beta=.703, \mathrm{p}<.01)$, satisfaction $(\beta$ $=.667, \mathrm{p}<.01)$, and repurchase intention $(\beta=.223, \mathrm{p}<.01)$, supporting hypotheses H1a, H1b, and H1c. To test hypothesis H1d, I calculated and bootstrapped the indirect effects in the path model (Hair et al., 2014) and found a significant indirect effect of two-way communication on WOM $(.623, \mathrm{p}<.01)$, supporting hypothesis H1d. In addition to the positive indirect relationship between two-way communication and WOM, I found three additional significant indirect effects: Two-way communication on repurchase intention $(.441, \mathrm{p}<.01)$, trust on WOM $(.092, \mathrm{p}<.01)$, and satisfaction on $\operatorname{WOM}(.144, \mathrm{p}<.01)$

Although not formally hypothesized, calculating and bootstrapping the indirect effects allowed us to investigate the potential mediating effects of the model (Hair et al., 2014). Specifically, the significant indirect effect of two-way communication on repurchase intention indicated that satisfaction and trust potentially mediate the effect of two-way communication on repurchase intention, while the significant indirect effects of trust and satisfaction on WOM indicated that repurchase intention potentially mediates the relationship between trust and WOM, and satisfaction and WOM. By following Preacher and Hayes (2008) in the mediation test, I first ensured that the direct relationship between two-way communication and repurchase intention is significant without including the mediator variables (i.e., trust and satisfaction) in the model and that the direct relationships between trust and WOM and between satisfaction and WOM were significant when excluding repurchase intention from the model. As I had already calculated and bootstrapped the indirect effects, I could proceed to calculate the variance accounted for (VAF) values, which determine the extent to which the variance of the dependent variable is explained by the indirect relationship via the mediator variable (Hair et al., 2014). As a result, it was found that trust and satisfaction partially mediate the relationship between two-way communication and repurchase intention with VAF values of $44.3 \%$ and $54.1 \%$, respectively. Similarly, repurchase intention partially mediates the relationships between trust and WOM (VAF $=20.8 \%)$ and between satisfaction and WOM $(\mathrm{VAF}=42.3 \%)$. Furthermore, it was found that the result was convergent across the subsamples (chat users and non-chat users) with only minor changes in the VAF values.

Taking into account the indirect effects led to important conclusions regarding the research model. First, even though two-way communication was found to have a much greater direct effect on trust $(.703, \mathrm{p}<.01)$ and satisfaction $(.667, \mathrm{p}<.01)$ compared to its direct effect on repurchase intention $(.223, \mathrm{p}<.01)$, the total effect of two-way communication on repurchase intention $(.644, \mathrm{p}<.01)$ was almost equally great. Moreover, when 
comparing the total effects on WOM, it was found that two-way communication had the greatest total effect on WOM $(.623, \mathrm{p}<.01)$ followed by trust $(.446, \mathrm{p}<.01)$, repurchase intention $(.366, \mathrm{p}<.01)$, and satisfaction $(.342, \mathrm{p}<.01)$. These results indicate that the extent to which consumers perceive that an e-retailer is dedicated to facilitating reciprocal communication on the e-commerce website not only has major influences on trust, satisfaction, and repurchase intention, but also on WOM intentions.

The PLS-MGA results demonstrated that there are significant differences between the chat users' and non-chat users' subsamples regarding the relationship strengths between two-way communication and trust $(.062, \mathrm{p}<.01)$ and between two-way communication and satisfaction $(.063, \mathrm{p}<.01)$. Specifically, the relationships were stronger in the chat users' subsample compared to non-chat users' subsample. Consequently, it is concluded that the use of chat service positively moderates the relationships between two-way communication and trust and between two-way communication and satisfaction ( $\mathrm{H} 2 \mathrm{a}$ and $\mathrm{H} 2 \mathrm{~b}$ supported).

On the contrary, no significant difference was found between the subsamples concerning the relationship between two-way communication and repurchase intention (.009ns; H2c not supported). However, this result can be explained by the indirect effect of two-way communication on repurchase intention via trust and satisfaction, which weaken the direct effect. Indeed, when the mediator variables of trust and satisfaction were removed from the model, the difference between the subsamples was found to be significant regarding the relationship between two-way communication and repurchase intention. This conclusion is further evidenced by investigating the indirect and total effects; I found a significant difference in the indirect $(.046, \mathrm{p}<.05)$ and total effect $(.055, \mathrm{p}$ $<.01$ ) of two-way communication on repurchase intention between the subsamples, suggesting that the use of chat service positively moderates the indirect and total effect of two-way communication on repurchase intention. Similarly, I found a significant difference between the indirect effect $(.076, \mathrm{p}<.01)$ of two-way communication on WOM, suggesting that the use of chat service strengthens this relationship. These results provide evidence for the important role of real-time communication in strengthening consumers' two-way communication perceptions and its effects on consumer attitudes.

Finally, in terms of control variables, I found that age, gender, and online shopping frequency had significant effects on trust, satisfaction, repurchase intention, and WOM with a few exceptions: the effects of gender and online shopping frequency were not significant on trust and WOM. However, by comparing the effect sizes ( $\mathrm{f}^{2}$ values) of control variables with those of principal constructs (see Table 6), it can be concluded that the relative impact that control variables have in producing $R^{2}$ values of the dependent variables are minor. Indeed, only the effect size of gender on repurchase intention $\left(f^{2}=.023\right)$ exceeds the threshold of .02 , which 
indicates a small effect (Cohen, 1988). Furthermore, the PLS-MGA results showed that the differences among control variable effects between the subsamples were not significant with one exception: gender had a significantly stronger relationship to WOM in the chat users' segment. This result suggests that male users of a chat service are more likely to share positive WOM about the retailers.

\section{Discussion}

This study extends the previous knowledge of the important role of computer-mediated communication in the eretailing sector by investigating the effects of two-way communication perceptions and the use of chat service on consumer attitudes and behavioral intentions. The results of a survey of 6,783 participants provided two important theoretical contributions. First, the study findings demonstrate that the extent to which a consumer perceives that the e-retailer fosters reciprocal communication on the website has major effects on consumer attitudes and behavioral intentions. Specifically, two-way communication was found to have significant and great effects on trust in and satisfaction with the e-retailer, as well as on repurchase intention, thus corroborating the existing findings in the field of website interactivity (e.g., Ballantine, 2005; Chiu et al., 2009; Dholakia \& Zhao, 2009; Merrilees \& Fry, 2003; Song \& Zinkhan, 2008). Furthermore, two-way communication was found to have the greatest effect on consumers' intentions to share positive WOM of the e-retailer in the research model, over satisfaction, trust, and repurchase intention. This is a remarkable finding given that the generation of positive WOM is often considered the ultimate marketing objective that is positively linked with firm performance (e.g., Reichheld, 2003; Trusov, Bucklin, \& Pauwels, 2009).

As its second important contribution, the present study is the first to demonstrate the positive moderating effects of the use of chat service on the relationship between two-way communication and consumer attitudes and behavioral intentions. While previous research has shown that the use of chat service has positive indirect effects on consumer attitudes via interactivity perceptions (Kang et al., 2015; Ou et al., 2014; Song \& Zinkhan, 2008), this study takes a novel approach and investigates the moderating effects of the use of chat service through the use of PLS-MGA. The results showed that the use of chat service significantly strengthens the direct effects of two-way communication on trust and satisfaction. Furthermore, the indirect and total effects of twoway communication on repurchase intention and WOM were significantly greater in the chat users' subsample than in the non-chat users' subsample. In sum, it is concluded that the use of chat service strengthens the effects of two-way communication on trust, satisfaction, repurchase intention, and WOM. This is an important finding 
considering the vital role of two-way communication in fostering positive consumer attitudes, as evidenced in this study.

Taken together, the study underscores the important role of two-way communication in building positive consumer attitudes and behavioral intentions on e-commerce websites and demonstrates how the use of a chat service strengthens these relationships. At the same time, it differs from previous interactivity literature by focusing on one dimension of perceived interactivity (i.e., two-way communication). To enhance our understanding of perceived interactivity, scholars are encouraged to report the effects of distinctive interactivity dimensions on dependent variables. In addition, the study questions if the use of a chat service is a meaningful antecedent of interactivity because the use of such a service is a type of interaction, which means the relationship is arguably axiomatic (i.e., the effect of interaction on interactivity). This study implies that the use of a chat service may act as a moderator, strengthening the relationship between interactivity perceptions and positive consumer attitudes and behavioral intentions.

From a managerial perspective, the study findings imply that interpersonal communication may be just as vital to online shopping as to offline shopping. While salespersons and customer service agents have always been a crucial part of shopping experiences in the physical stores, the same phenomenon is likely to become more prominent in the online shopping environment, as live chat interfaces and other similar technological solutions become more widespread. As the study findings implied that chat service might bring long-term benefits to companies in terms of customer retention and positive WOM, I recommend managers consider the adoption of such a service. The potential long-term benefits also suggest that a chat service should not have an excessive sales orientation but rather be used as a tool to build customer relationships via meaningful interactions. Notably, simply adopting a chat service may not be enough, as the company must also ensure that it has sufficient resources to manage the communication flows. Another option is to outsource the chat service to an agent as the companies under investigation have successfully done.

The major limitation of this study is its generalizability. Although the number of observations was large $(\mathrm{N}=6,783)$, the data were only collected from the customers of five Finnish e-retailers. Moreover, I only investigated an outsourced chat service operated by a single service provider. Therefore, the results might have varied to some extent had I investigated other e-retailers, chat service providers, or consumers from other countries. Therefore, more research is needed to generalize the study findings and to advance the theoretical understanding regarding the effects of real-time communication on consumer attitudes and purchasing behaviors. Some promising areas include investigating the effects of a chat service on social presence and social bonding. It 
is important to understand whether the conversations held via mediated chat interfaces are perceived by consumers as real human-to-human interactions, where both parties are psychologically present, and if continuous interactions via the chat interface lead to the creation of social bonds between the conversation parties. Notably, many companies have replaced human chat service agents with "chatbots" through the use of artificial intelligence. Therefore, it would be important to study how consumer perceptions differ between chat services provided by humans and robots. In addition to a chat service, researchers should also consider other related technologies that foster online communication between consumers and e-retailers, as well as consumerto-consumer communication. 


\section{References}

Anderson, R. E., \& Srinivasan, S. S. (2003). E-satisfaction and e-loyalty: A contingency framework. Psychology and Marketing, 20(2), 123-138.

Armstrong, J. S., \& Overton, T. S. (1977). Estimating Nonresponse Bias in Mail Surveys. Journal of Marketing Research, 14(3), 396-402.

Ballantine, P. W. (2005). Effects of interactivity and product information on consumer satisfaction in an online retail setting. International Journal of Retail \& Distribution Management, 33(6), 461-471.

Brown, T. J., Barry, T. E., Dacin, P. A., \& Gunst, R. F. (2005). Spreading the word: Investigating antecedents of consumers' positive word-of-mouth intentions and behaviors in a retailing context. Journal of the Academy of Marketing Science, 33(2), 123-138.

Chiou, J.-S., Droge, C., \& Hanvanich, S. (2002). Does customer knowledge affect how loyalty is formed? Journal of Service Research, 5(2), 113-124.

Chiu, C.-M., Chang, C.-C., Cheng, H.-L., \& Fang, Y.-H. (2009). Determinants of customer repurchase intention in online shopping. Online Information Review, 33(4), 761-784.

Cohen, J. (1988). Statistical power analysis for the behavioral sciences. Hillsdale: L. Erlbaum.

Cyr, D., Head, M., \& Ivanov, A. (2009). Perceived interactivity leading to e-loyalty: Development of a model for cognitive-affective user responses. International Journal of Human-Computer Studies, 67(10), 850-869.

DeFleur, M.L., \& Ball-Rokeach, S.J. (1989). Theories of Mass Communication. (5 ${ }^{\text {th }}$ ed.) New York: Longman.

Dholakia, R. R., \& Zhao, M. (2009). Retail web site interactivity: How does it influence customer satisfaction and behavioral intentions? International Journal of Retail \& Distribution Management, 37(10), 821-838.

Doney, P. M., \& Cannon, J. P. (1997). An examination of the nature of trust in buyer-seller relationships. Journal of Marketing, 61(2), 35-51.

Econsultancy. (2017). Seven retailers that use live chat to improve customer service. [Accessed 14 October 2017]. Available at: https://econsultancy.com/blog/68898-seven-retailers-that-use-live-chat-to-improvecustomer-service

Fornell, C., Johnson, M. D., Anderson, E. W., Cha, J., \& Bryant, B. E. (1996). The American Customer Satisfaction Index: Nature, purpose, and findings. Journal of Marketing, 60(4), 7-18.

Fornell, C., \& Larcker, D. F. (1981). Evaluating structural equation models with unobservable variables and measurement error. Journal of Marketing Research, 18(1), 39-50.

Forrester. (2016). Online self service dominates yet again. Why? Its an effortless way to get your answers. [Accessed 22 October 2017]. Available at: https://go.forrester.com/blogs/16-01-28online_self_service_dominates_yet_again_why_its_an_effortless_way_to_get_to_your_answers/

Ganesan, S. (1994). Determinants of long-term orientation in buyer-seller relationships. Journal of Marketing, $58(2), 1-19$.

Gold, A. H., Malhotra, A., \& Segars, A. H. (2001). Knowledge management: An organizational capabilities perspective. Journal of Management Information Systems, 18(1), 185-214.

Gremler, D. D., Gwinner, K. P., \& Brown, S. W. (2001). Generating positive word-of-mouth communication through customer-employee relationships. International Journal of Service Industry Management, 12(1), 44-59.

Gruen, T. W., Osmonbekov, T., \& Czaplewski, A. J. (2006). eWOM: The impact of customer-to-customer online know-how exchange on customer value and loyalty. Journal of Business Research, 59(4), 449456.

Ha, L., \& James, E. L. (1998). Interactivity reexamined: A baseline analysis of early business web sites. Journal of Broadcasting \& Electronic Media, 42(4), 457-474.

Ha, H.-Y., Janda, S., \& Muthaly, S. K. (2010). A new understanding of satisfaction model in e-re-purchase situation. European Journal of Marketing, 44(7/8), 997-1016. 
Hair, J. F, Hult, T. M., Ringle, C. M., \& Sarstedt, M. (2014). A primer on partial least squares structural equation modeling (PLS-SEM). Thousand Oaks: Sage.

Heitmann, M., Lehmann, D. R., \& Herrmann, A. (2007). Choice goal attainment and decision and consumption satisfaction. Journal of Marketing Research, 44(2), 234-250.

Hennig-thurau, T., Gwinner, K. P., \& Gremler, D. D. (2002). Understanding relationship marketing outcomes: An integration of relational benefits and relationship quality. Journal of Service Research, 4(3), 230-247.

Henseler, J., Ringle, C. M., \& Sarstedt, M. (2015). A new criterion for assessing discriminant validity in variance-based structural equation modeling. Journal of the Academy of Marketing Science, 43(1), 115135.

Henseler, J., Ringle, C. M., \& Sinkovics, R. R. (2009). The use of partial least squares path modeling in international marketing. Advances in International Marketing, 20, 277-319.

Hoffman, D. L., \& Novak, T. P. (1996). Marketing in hypermedia computer-mediated environments: Conceptual foundations. Journal of Marketing, 60(3), 50-68.

Jiang, Z., Chan, J., Tan, B. C. Y., \& Chua, W. S. (2010). Effects of interactivity on website involvement and purchase intention. Journal of the Association for Information Systems, 11(1), 34-59.

Jones, M. A., \& Reynolds, K. E. (2006). The role of retailer interest on shopping behavior. Journal of Retailing, 82(2), 115-126.

Kang, L., Wang, X., Tan, C.-H., \& Zhao, J. L. (2015). Understanding the antecedents and consequences of live chat use in electronic markets. Journal of Organizational Computing and Electronic Commerce, 25(2), 117-139.

Khalifa, M., \& Liu, V. (2007). Online consumer retention: Contingent effects of online shopping habit and online shopping experience. European Journal of Information Systems, 16(6), 780-792.

Kim, T. T., Kim, W. G., \& Kim, H. B. (2009). The effects of perceived justice on recovery satisfaction, trust, word-of-mouth, and revisit intention in upscale hotels. Tourism Management, 30(1), 51-62.

Kiousis, S. (2002). Interactivity: a concept explication. New Media \& Society, 4(3), 355-383.

Liu, Y. (2003). Developing a scale to measure the interactivity of websites. Journal of Advertising Research, 43(3), 207-216.

Lv, Z., Wang, X., \& Huang, J. (2016). Effect of instant messenger use on purchase decision of consumers. In 13th International Conference on Service Systems and Service Management (ICSSSM) (pp. 1-6). IEEE.

McMillan, S. J., \& Hwang, J.-S. (2002). Measures of perceived interactivity - An exploration of the role of direction of communication, user control, and time in shaping perceptions of interactivity. Journal of Advertising, 31(3), 29-42.

Merrilees, B., \& Fry, M.-L. (2003). E-trust: the influence of perceived interactivity on e-retailing users. Marketing Intelligence \& Planning, 21(2), 123-128.

Mollen, A., \& Wilson, H. (2010). Engagement, telepresence and interactivity in online consumer experience: Reconciling scholastic and managerial perspectives. Journal of Business Research, 63(9-10), 919-925.

Morgan, R. M., \& Hunt, S. D. (1994). The Commitment-trust theory of relationship marketing. Journal of Marketing, 58(July), 20-38.

Munnukka, J., Karjaluoto, H., \& Tikkanen, A. (2015). Are Facebook brand community members truly loyal to the brand? Computers in Human Behavior, 51, 429-439.

Nunally, J. C., \& Bernstein, I. (1994). Psychometric theory. New York: McGraw-Hill.

Ou, C. X., Pavlou, P. A., \& Davison, R. M. (2014). Swift guanxi in online marketplaces: The role of computermediated communication technologies. MIS Quarterly, 38(1), 209-230.

Pavlik, J.V. (1998). New media technology: Cultural and commercial perspectives. (2 ${ }^{\text {nd }}$ ed.) Boston: Allyn and Bacon.

Podsakoff, P. M., MacKenzie, S. B., Lee, J.-Y., \& Podsakoff, N. P. (2003). Common method biases in behavioral research: a critical review of the literature and recommended remedies. The Journal of Applied Psychology, 88(5), 879-903. 
Preacher, K. J., \& Hayes, A. F. (2008). Asymptotic and resampling strategies for assessing and comparing indirect effects in multiple mediator models. Behavior Research Methods, 40(3), 879-891.

Rafaeli, S. (1988). Interactivity: From new media to communication. In Advancing Communication Science: Merging Mass and Interpersonal Processes. CA: Sage, 110-34.

Ranaweera, C., \& Prabhu, J. (2003). On the relative importance of customer satisfaction and trust as determinants of customer retention and positive word of mouth. Journal of Targeting, Measurement and Analysis for Marketing, 12(1), 82-90.

Reichheld, F. F. (2003). The one number you need to grow. Harvard Business Review, 81(December), 46-54.

Ribbink, D., Riel, A. C. R. Van, Liljander, V., \& Streukens, S. (2004). Comfort your online customer: quality, trust and loyalty on the internet. Managing Service Quality, 14(6), 446-456.

Ringle, C. M., Wende, S., \& Becker, J. (2014). SmartPLS 3, Retrieved from: https://www.smartpls.com/

Rose, S., Clark, M., Samouel, P., \& Hair, N. (2012). Online customer experience in e-retailing: An empirical model of Antecedents and Outcomes. Journal of Retailing, 88(2), 308-322.

Sarstedt, M., Henseler, J., \& Ringle, C. M. (2011). Multigroup analysis in partial least squares (PLS) path modeling - Alternative methods and empirical results. Advances in International Marketing, 22(July), 195-218.

Sarstedt, M., Ringle, C. M., Smith, D., Reams, R., \& Hair, J. F. (2014). Partial least squares structural equation modeling (PLS-SEM): A useful tool for family business researchers. Journal of Family Business Strategy, 5(1), 105-115.

Sichtmann, C. (2007). An analysis of antecedents and consequences of trust in a corporate brand. European Journal of Marketing, 41(9/10), 999-1015.

Sirdeshmukh, D., Singh, J., \& Sabol, B. (2002). Consumer trust, value, and loyalty in relational exchanges. Journal of Marketing, 66(1), 15-37.

Song, J. H., \& Zinkhan, G. M. (2008). Determinants of perceived web site interactivity. Journal of Marketing, 72(March), 99-113.

Srinivasan, S. S., Anderson, R., \& Ponnavolu, K. (2002). Customer loyalty in e-commerce: an exploration of its antecedents and consequences. Journal of Retailing, 78(1), 41-50.

Steuer, J. (1992). Defining virtual reality: Dimensions determining telepresence. Journal of Communication, 42(4), 73-93.

Söderlund, M. (2006). Measuring customer loyalty with multi-item scales: A case for caution. International Journal of Service Industry Management, 17(1), 76-98.

Teo, T. S. H., Srivastava, S. C., \& Jiang, L. (2008). Trust and electronic government success: An empirical study. Journal of Management Information Systems, 25(3), 99-131.

Trusov, M., Bucklin, R. E., \& Pauwels, K. (2009). Effects of word-of-Mouth versus traditional marketing: Findings from an Internet social networking site. Journal of Marketing, 73(5), 90-102.

Wangenheim, F. V, \& Bayón, T. (2007). The chain from customer satisfaction via word-of-mouth referrals to new customer acquisition. Journal of the Academy of Marketing Science, 35(2), 233-249.

Westbrook, R. A. (1987). Product/consumption based affective responses and postpurchase processes. Journal of Marketing Research, 24(3), 258-270.

Williams, F., Rice, R. E., \& Rogers, E. M. (1988). Research Methods and the New Media. New York: Free Press

Wu, G. (1999). Perceived interactivity and attitude toward web sites. In Proceedings of the American Academy of Advertising, 254-262.

Wu, G. (2006). Conceptualizing and measuring the perceived interactivity of websites. Journal of Current Issues \& Research in Advertising, 28(1), 87-104.

Wu, G., Hu, X., \& Wu, Y. (2010). Effects of perceived interactivity, perceived web assurance and disposition to trust on initial online trust. Journal of Computer-Mediated Communication, 16(1), 1-26.

Zeithaml, V. A., Berry, L. L., \& Parasuraman, A. (1996). The behavioral consequences of service quality. Journal of Marketing, 60(April), 31-46. 


\section{Appendix A - Constructs and items}

\begin{tabular}{|c|c|c|c|}
\hline \multirow[t]{2}{*}{ Construct/Item } & \multicolumn{3}{|c|}{ Factor loading } \\
\hline & $\begin{array}{c}\text { All } \\
\text { respon- } \\
\text { dents }\end{array}$ & $\begin{array}{l}\text { Chat } \\
\text { users }\end{array}$ & $\begin{array}{l}\text { Non-chat } \\
\text { users }\end{array}$ \\
\hline \multicolumn{4}{|l|}{ Two-way communication (Liu, 2003) } \\
\hline $\mathrm{X}$ gives visitors the opportunity to talk back on the website. & .674 & 666 & 670 \\
\hline It is easy to offer feedback to $X$ on the website. & .824 & .806 & .829 \\
\hline $\mathrm{X}$ facilitates two-way communication between the visitors and the site. & .866 & .881 & .858 \\
\hline $\mathrm{X}$ makes me feel it wants to listen to its visitors. & .863 & .870 & .859 \\
\hline \multicolumn{4}{|l|}{ Trust (Doney \& Cannon 1997; Wu et al., 2010) } \\
\hline $\mathrm{X}$ keeps its promises and commitments. & .884 & .898 & .878 \\
\hline I believe in the information that $\mathrm{X}$ provides me. & .892 & .902 & .888 \\
\hline $\mathrm{X}$ is trustworthy. & .892 & .896 & .890 \\
\hline \multicolumn{4}{|l|}{ Satisfaction (Fornell et al. 1996; Ha et al. 2010) } \\
\hline How satisfied are you with $\mathrm{X}$ ? & .952 & .956 & .951 \\
\hline How well does $\mathrm{X}$ match your expectations? & .944 & .952 & .941 \\
\hline Imagine a perfect e-commerce store. How close to this ideal is $\mathrm{X}$ ? & .917 & .927 & .912 \\
\hline How satisfied are you with your overall experience with $X$ ? & .931 & .938 & .928 \\
\hline \multicolumn{4}{|l|}{ Repurchase intention (Srinivasan et al., 2002; Khalifa \& Liu, 2007) } \\
\hline I consider $\mathrm{X}$ as my first choice to buy $\mathrm{Y}$ products/services. & .861 & .860 & .861 \\
\hline $\begin{array}{l}\text { As long as the present service continues, I doubt that I would switch } \\
\text { my purchases to another e-commerce store. }\end{array}$ & .860 & .871 & .856 \\
\hline It is likely that I will repurchase from $\mathrm{X}$ in the near future. & .831 & .812 & .837 \\
\hline I expect to repurchase from $X$ in the near future. & .887 & .885 & .887 \\
\hline \multicolumn{4}{|l|}{ Word-of mouth (Srinivasan et al., 2002) } \\
\hline I encourage friends and relatives to do business with $X$. & .905 & .919 & .899 \\
\hline I say positive things about $\mathrm{X}$ to other people. & .921 & .925 & .920 \\
\hline I do not hesitate to refer my acquaintances to $X$. & .904 & .912 & .902 \\
\hline
\end{tabular}

Notes: $\mathrm{X}$ refers to the name of the focal e-commerce store; $\mathrm{Y}$ refers to specific types of products/services offered by an e-retailer; Items were measured using a 7-point Likert scale (anchors: "1" = strongly disagree, "7" = strongly agree), except for satisfaction which was measured with a 10-point Likert scale. 